\title{
Investigation of Permeable Pavement Implementation in Baghdad Using PCSWMM Model
}

\author{
Hayat Kareem Shukur Azawi ${ }^{1} \&$ Dawood Eisa Sachit ${ }^{2}$ \\ ${ }^{1}$ Civil Engineering Department, Mustansiriyah University, Baghdad 10047, Iraq \\ ${ }^{2}$ Environmental Engineering Department, Mustansiriyah University, Baghdad 10047, Iraq \\ Correspondence: Hayat Kareem Shukur Azawi, Civil Engineering Department, Mustansiryai University, \\ Baghdad 10047, Iraq. Tel: 964-781-953-6883. E-mail: hayat.azawi@okstate.edu
}

Received: July 31, 2018

Accepted: August 28, 2018

Online Published: September 19, 2018

doi:10.5539/enrr.v8n3p117

URL: https://doi.org/10.5539/enrr.v8n3p117

\begin{abstract}
One of the most important reasons for the frequent occurrence of rainwater flooding in Baghdad in general and Al-Huryai, part of Baghdad, in particular is the lack of runoff drainage systems in conventional pavement. Incidents of flooding have occurred on an average three times per year in many parts of the town due to heavy rain of high intensity and short duration. Using permeable pavement will help to control flooding and improve public health. The objective of this study is to investigate the important factors that describe the possible implementation of permeable pavement in Al-Huryai city using PCSWMM software and to quantify the effectiveness of this technique on the hydrologic response of the case study by comparing the simulation analyses of the site under its undeveloped condition, after development, and after implementing permeable pavement. The simulation results showed that permeable pavement approach has a significant impact on runoff reduction.
\end{abstract}

Keywords: stormwater management, permeable pavement, sustainability; PCSWMM software; urban watershed

\section{Introduction}

When the rate of population growth increases, the rate of land development will also increase causing more flooding problems. It is estimated that from 2010 to 2050 the Iraqi population will increase by 3.6 percent. This rate is considered very high. It was recommended to be reduced to 1.9 percent (El-Mooty et al., 2016). Stormwater runoff is generated when precipitation from rain does not percolate into the ground, eventually causing reduction in the groundwater recharge and increasing in flooding events (USEPA, 2012). In addition, the hydrologic systems are currently being impacted by extreme rainfall events with high intensity and short duration. For instant, (Shen et al., 2018) showed a strong relationship between high temperatures and heavy rain as a result of climate change. This will lead to increases in the probability of flooding in the near future. Baghdad, the capital of Iraq, is subject to flooding at many areas due to heavy rain. Incidents happen on an average of three times per year. Recently on Feb 16, 2018, an incident caused road flooding and economic loss from pumping water out of ponded areas. Therefore, a new design for Baghdad's drainage system is needed. Low Impact Development (LID), a new stormwater management, is widespread around the world and could be used in any type of soils and in different methods to decrease the runoff problems by increasing both infiltration and evaporation (Abaas, 2013).

Permeable pavement, one of the most important applications of LID, has been widely used nowadays in many countries for its effectiveness in reducing the amount of runoff as close to the source as possible (Gupta, 2017; Eckart, 2017). Many studies have been done on permeable pavement. For instant, Abaas, 2013 recommended using LID techniques in the Faculty Housing Complex in Baghdad University. The study suggested a number of solutions and viable strategies in order to develop the study area to a sustainable residential project by using green infrastructure. One solution is establishing permeable pavement in children's play areas, parking lots, tennis courts, and football fields for ensuring the possibility of infiltration. In addition, another study in Dubai was conducted by Kfoury et al., 2015 where similar conditions to Iraq exist. The study demonstrated how permeable pavement greatly effects runoff reduction. The researchers examined four porous concrete mixture designs using the available materials to achieve acceptable strength, permeability, and surface quality. Out of the four, the porous concrete with acceptable permeability $(0.005 \mathrm{~cm} / \mathrm{s})$, flexural strength $(3.2 \mathrm{MPa})$ and 
compressive strength (22 MPa) was recommended to be used. The clogging factor for porous concrete due to sand and dust exposure is acceptable, and it is not an obstacle for permeable pavement implementation. Moreover, the study revealed that porous concrete disadvantages including high susceptibility to freeze-thaw cycles and low flexural strength are not considered a problem in the Middle East where no freezing and thawing occur.

Al-jumaili, 2016 compared the influence of two modifier types (styrene-butadiene styrene [SBS] and propylene modifier [PP] on the porous asphalt mixtures performance using local materials in Iraq. The porous asphalt mixture (PAM) evaluation was based on void, asphalt flow drain, and abrasion resistance. Porous asphalt with $5 \%$ was the most effective while the PP had no effect on mixture strength. A mixture with marshal stability 12.4 $\mathrm{KN}$, marshal flow $2.8 \mathrm{~mm}$ and marshal stiffness $4.43 \mathrm{KN} / \mathrm{mm}$ elucidates high marshal stiffness among other porous mixture. The results showed that porous stiffness is the most important parameter that causes failure. To improve mixture stiffness, a modifier can be added. Rojas et al., 2018 analyzed the hydrologic response of three types of permeable pavement which were implemented in Granada, Spain to assess the impact on runoff reduction, and $70 \%$ efficiency was obtained for delaying the catchment area response. Globally, many studies have been conducted on LID techniques in general and permeable pavement in particular. Chang, 2018 presented a brief study of the (LID) implementation in several countries such as China, Japan, Australia as well as Los Angeles in the United States. The study effectively explained how these techniques are perceived in different attitudes by the western and eastern communities around the global. For instant, the western parts such as United States have focused on restoring water quality whereas Eastern parts pay more attention to flood control and rain water harvesting. Public participation in LID implementation is very important. The increase in community education in implementing LID practices in their properties will help these communities understand its benefits. In China, the requirement of implementing LID elements was issued in 2013. The requirements include no less than 500 cubic meters of rainwater storage facilities for every hectare of hard ground no less than a $70 \%$ porous flow rate for pavement. Permeable pavement allows water to infiltrate up to 80 percent of annual runoff volume, needs less concrete collection pipes and storage systems, and improves driving safety. Other advantages are reducing pollutant load, recharging groundwater and reducing tire-pavement noise (Al-jumaily, 2016; Kfoury et al., 2015). Stormwater reuse can help meet the growing water demand, and permeable pavement is valuable in accomplishing this task.

Al-Huryai city, located in Baghdad, Iraq, has currently experienced an increase in population and land development during the last decades. This led to stormwater flooding in many parts of the town including residential areas. This study examines the possibility of implementing permeable pavement in garages, parking lots; children's plays areas at schools, and people yards to minimize the negative impact of streets flooding during heavy rains. The permeable pavement was undertaken using PCSWMM software. PCSWMM, one of the most comprehensive urban runoff models and support system for EPA (SWMM5), was chosen for use in this study for its ability to effectively simulate continuous runoff quantity in urban areas. The runoff components in PCSWMM function on a collection of subcatchment areas that receive precipitation and generate runoff. The routing components transport this runoff through a system of pipes, storage units, and other structures (James et al., 2010). Computerized solutions can be more detailed than hand calculations with less error and with less amount of time (Haestad Press, 2004). The objective was to create three models. The first model represents the study area in its undeveloped state (Al-Huryai as-is). The second represents the site condition after development (Al-Huryai_PosDev), and the third model simulates the site after implementing permeable pavement (Al-Huryai-PP).The three scenarios were modeled and compared to see the effect of permeable pavement on runoff reduction. The simulation results revealed that the permeable pavement has a significant impact on runoff reduction and thus, decreases the possibility of flooding problems.

\section{Materials and Method}

\subsection{Site Description}

Al-Huryai is located in the west of Baghdad, Iraq. It has a climate between continental and subtropical with average annual precipitation of about $213 \mathrm{~mm}$ per year (Al-Ansari et al., 2014) and average temperatures ranging from $48 \mathrm{C}^{\circ}$ in summer to below $0 \mathrm{C}^{\circ}$ in winter (Shubbar et al., 2016). The site is currently managed with combined sewer systems where both sanitary and storm flow can be disposed. The system consists of subsidiary and main sewer networks that are insufficient during heavy rain which frequently causes streets to flood. The soil consists of sand, silt and clay (Abdullah, 2013) which is referred to (B) NRCS (Natural Resources Conservation Service) soil type. The Green-Ampt Method was used for modeling the infiltration. The three most important input parameters in this method are the hydraulic conductivity $(0.152 \mathrm{~cm} / \mathrm{hr})$, suction head $21.99 \mathrm{~cm}$, and initial deficit (0.136) (James et al., 2012). Depression storage (Dstore-Imperv) defines as a volume that must 
be filled prior to the occurrence of any runoff. It ranges between 0.05 in for impervious surfaces to 0.3 in for forested areas as shown in Table 1.

Data of a historic rainfall from 2014-2015 was obtained from the Meteorology office gage station \#40650 in Baghdad. A 15-minute period of data was used since it explains the variation of actual rainfall data better than other interval data. The rain gauge was created using the time series editor in PCSWMM model. The hyetograph for the watershed is as shown in Figure 1.

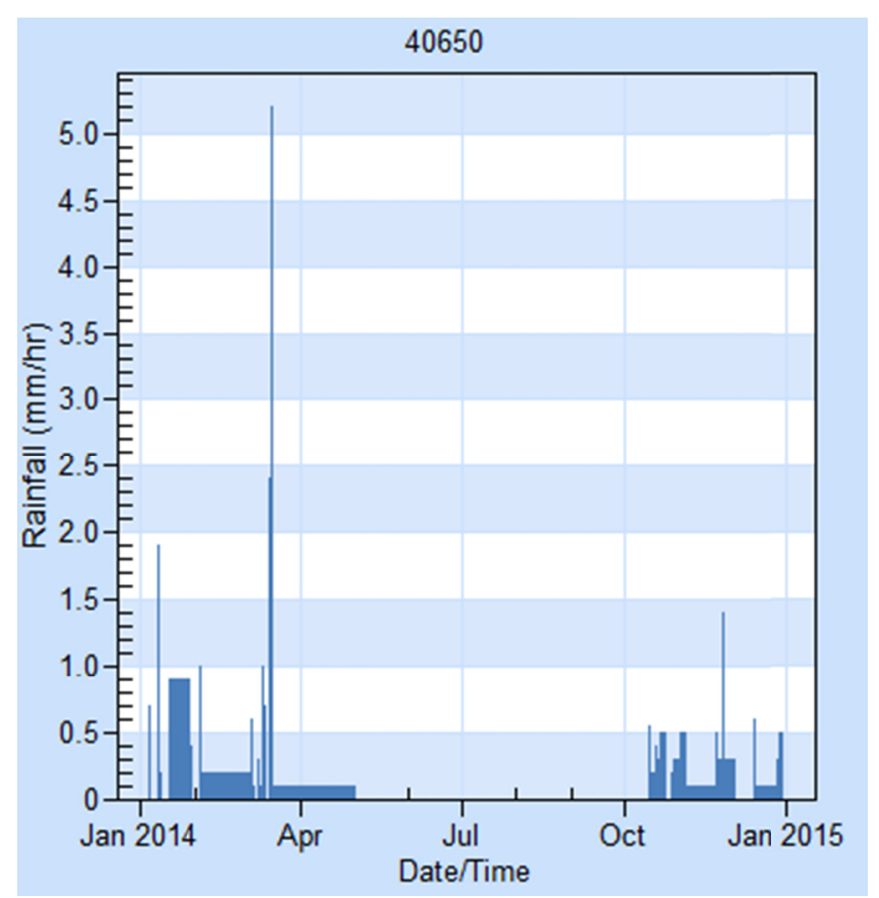

Figure 1. Hyetograph for the case study using PCSWMM software

The site was analyzed based on existing conditions at Al-Huryai case study where combined sewer networks were adopted for conveyance. The area consists of $76 \%$ impervious and $24 \%$ pervious and open spaces with average slope of $0.05 \% .21$ subcathments were created to simulate the site in its post development state as shown in Figure 2. However, the predevelopment scenario (Al-Huryai as-is) was created by using the join button in the tool bar in PCSWMM as shown in Figure 3 and 4. The predevelopment model was composed of $100 \%$ grass and zero impervious areas. This scenario was used for comparison with two other scenarios, which are Al-Huryai PostDev and Al-Huryai- PP. The Al-Huryai- PP was modeled by placing permeable pavement in an existing subcathment that displaced an equal amount of impervious area from the subcathment. The goal was to reduce the percentage of directly connected impervious areas and mimic the runoff characteristic of the site in its undeveloped condition as closely as possible. The characteristics of the pre-development scenario are as shown in Table 2.

After permeable pavements placement the subcatchment's percent impervious and width properties need adjustment to compensate for the amount of original subcatchment area that has now been replaced by permeable pavement. The width can be defined as the subcatchment's area divided by the length of the longest overland flow path that water can travel. 


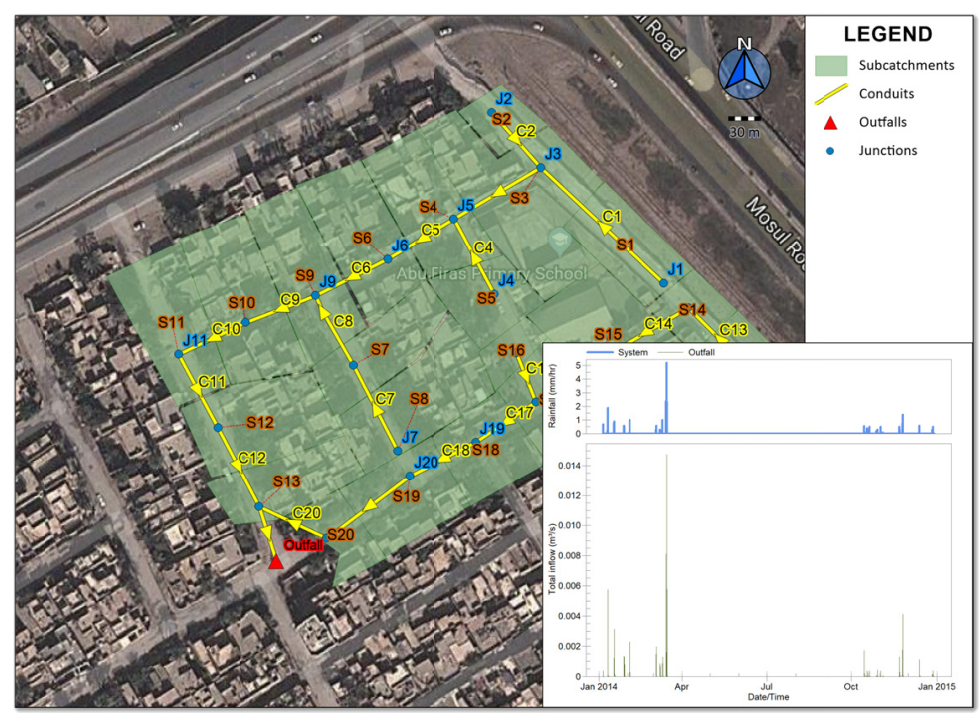

Figure 2. Al-Huryai_PotDev scenario (continuous simulation period from January 2014 to January 2015) using PCSWMM software

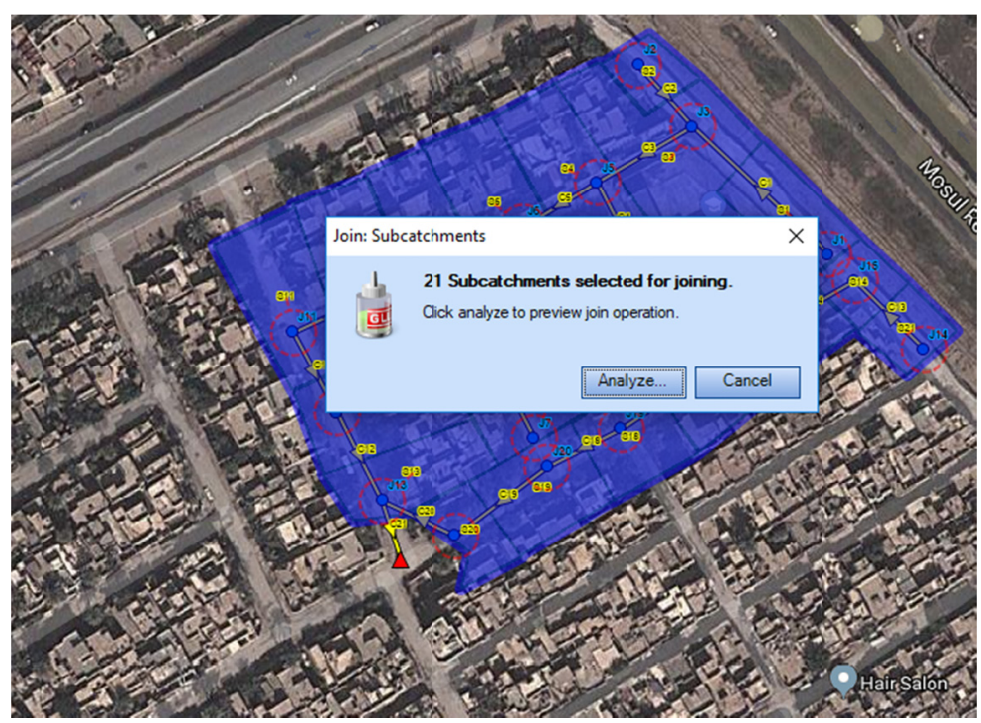

Figure 3. Al-Huryai-as is a scenario using join button in the tool bar of PCSWMM software.

Table 1. Model parameters inputs in PCSWMM

\begin{tabular}{lrr}
\hline Parameter & Value & Source \\
\hline Depression Storage & & \\
$\quad$ Pervious (Dstore-Perv) & $0.508 \mathrm{~cm}$ & (James, et al. 2010) \\
$\quad$ Impervious( Dstore-Imperv) & $0.127 \mathrm{~cm}$ & (James, et al. 2010), \\
Manning's n for overland flow & & \\
$\quad$ Native Grass (N-Perv) & 0.2 & (James, et al. 2010) \\
$\quad$ Impervious (N-Imperv) & 0.013 & \\
RainGage & $\# 40650$ & Meteorological office, Baghdad \\
Percent Routed & 100 & \\
Zero Imperv (\%) & 25 & \\
Soil & & \\
$\quad$ Infiltration rate & $0.152 \mathrm{~cm} / \mathrm{hr}$ & (James, et al. 2010) \\
Suction Head & $21.99 \mathrm{~cm}$ & \\
Conduits & & \\
$\quad$ Cross-Section & Circular & (Durrans, 2003) \\
$\quad$ Manning's n & 0.013 & \\
$\quad$ & &
\end{tabular}




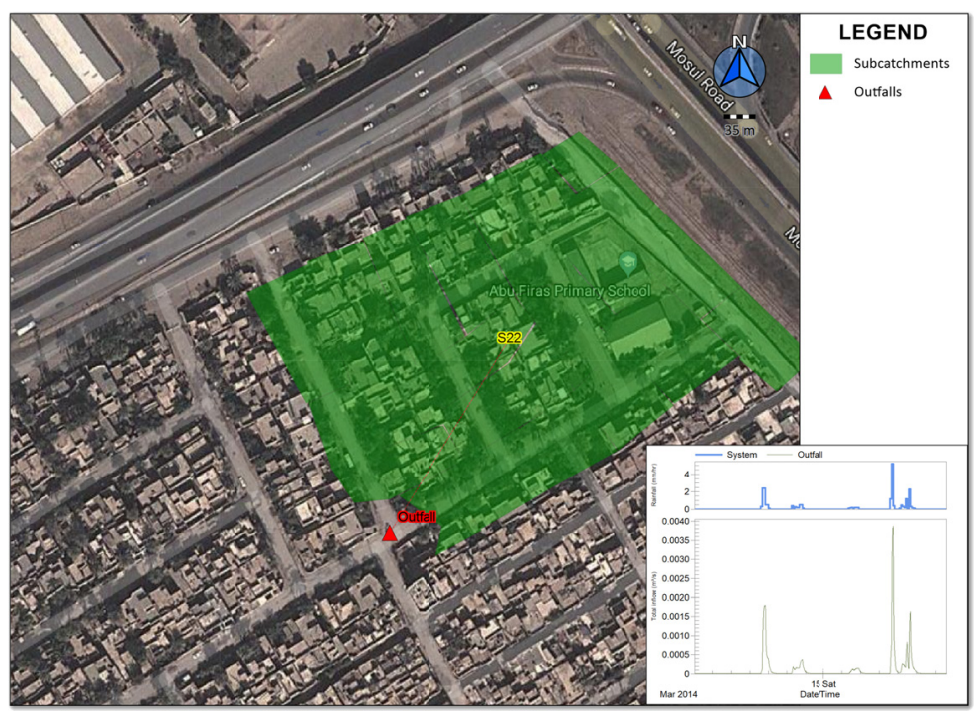

Figure 4. Predevelopment (S22) condition with one outlet

The characteristics of the pre-development scenario are as shown in Table 2 below:

Table 2. Characteristics of the pre-development scenario

\begin{tabular}{lcccccc}
\hline Name & Area, ha & Width, $m$ & \% imperv & \%Slope & Rain Gage & Outlet \\
\hline S22 & 1.80 & 90 & 0 & 0.05 & 40650 & Outfall \\
\hline
\end{tabular}

\subsection{Dust in Iraq}

Sandstorms usually sweep across the country and cause many problems for agriculture and for public health. Moreover, it is the main concern in permeable pavement service life. According to the monthly distribution of dust storms, June, July and April are the main periods of dust activity in Iraq. A studies done by Pereze et al., 2017; Abdulla, et al., 1988; Crook, 2009 on dust storm in Iraq indicated that $72 \%$ of the dust samples were sandy clayey, and $28 \%$ were clayey sandy silt. The dust samples were composed of quartz, feldspars, and calcite, with small amount of gypsum. The average dust loading is equal to $0.57 \mathrm{~kg} / \mathrm{m} 2$. In general the term sand storm is used for particles with average diameters between 2.0 and $0.06 \mathrm{~mm}$ while the term dust storm is used for particles of silt and clay with average diameter less than $0.06 \mathrm{~mm}$. The mean annual dust storms in Baghdad (1990-1951) were determined to be 12 days Pereze et al., 2017. The clogging of the permeable pavement due to sand or dust is progressively reducing its permeability in direct proportion to the cumulative volume of runoff treated. The clogging factor can be calculated using the following formula James et al., 2010. However, when ignoring the clogging factor, a zero value can be used.

$$
\text { Clogging Factor }=\left[Y_{C l o g} \times P_{a} \times C R \times(1+V R)\right] \frac{(1-I S F)}{(T \times V R)}
$$

Where:

$Y_{\text {Clog }}=$ numbers of years it takes to fully clog the system,

$P_{a} \quad=$ Annual rainfall amount over the site

$\mathrm{CR}=$ pavement capture ratio

$\mathrm{VR}=$ Void ratio of the system

ISF $=$ Impervious Surface Fraction and

$\mathrm{T} \quad=$ Pavement layer thickness.

\subsection{Permeable Pavement Structure}

Permeable pavement (Figure 5), an alternative to traditional impervious pavement, allows stormwater to drain through it and into a storage layer where it infiltrates into the underlying native soil or temporarily detained. 
They can be used for low traffic roads, parking lots, driveways, pedestrian plazas and walkways. Pervious research has shown that, the native soil under the permeable pavement has a great impact on permeable pavement design. For example, high soil permeability such as gravel and sand are suitable for self-draining permeable pavement while soil such as clay needs a drainage system for draining water (Prince George's County, 1999). Moreover, flat surfaces help store the water on the pavement long enough until it infiltrate. Infiltration rates of at least 0.5 inches per hour led to stormwater flooding in many parts of the town including residential areas $(0.197 \mathrm{~cm} / \mathrm{hr})$ are recommended for the porous pavement (James et al, 2010). The storage layer can serve in two ways: (1) to transvers the traffic load from the surface (pavement layer) to the natural soil layer, and (2) to store water for a period of time.

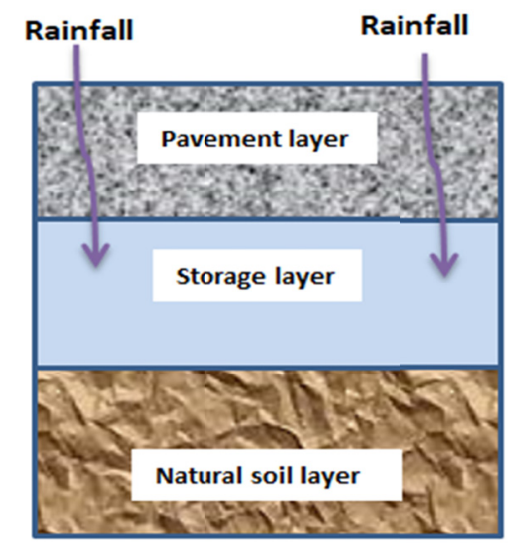

Figure 5. Permeable pavement structure

\section{Results and Discussion}

The water balance in Baghdad requires post construction runoff control. In recent years, flooding has occurred in many areas of the city. The main objective of this study is to increase the percentage of non-directly impervious areas (NDIA) by implementing permeable pavements. Three scenarios (Al-Huryai as-is, Alhuryai_PosDev, and Al-Huryai-PP) were created and modeled with continuous time series data using PCSWMM. This type of simulation analyzes the performance of Al-Huryai-PP over a long period of time to see the effects of stormwater controls. The comparison between the post and the predevelopment models at the beginning, the middle, and the end of simulation is as shown in Figures 6, 7, and 8, respectively.

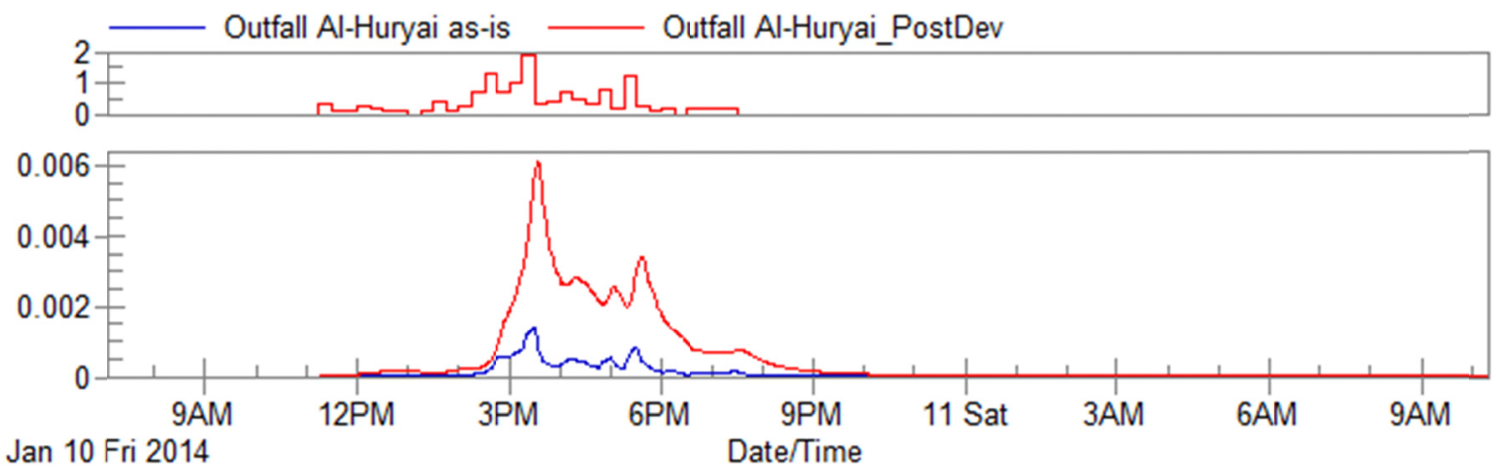

Figure 6. Comparisons simulation between Al-Huryai as-is and Al-Huryai_PosDev at the beginning of simulation period 


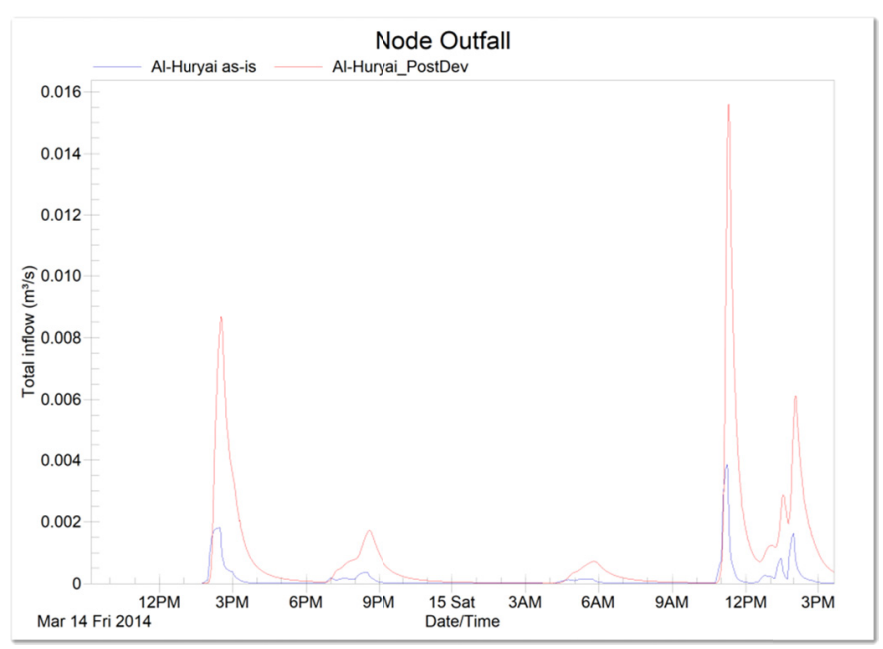

Figure 7. Comparisons simulation between Al-Huryai as-is and Al-Huryai_PosDev at the middle of simulation period

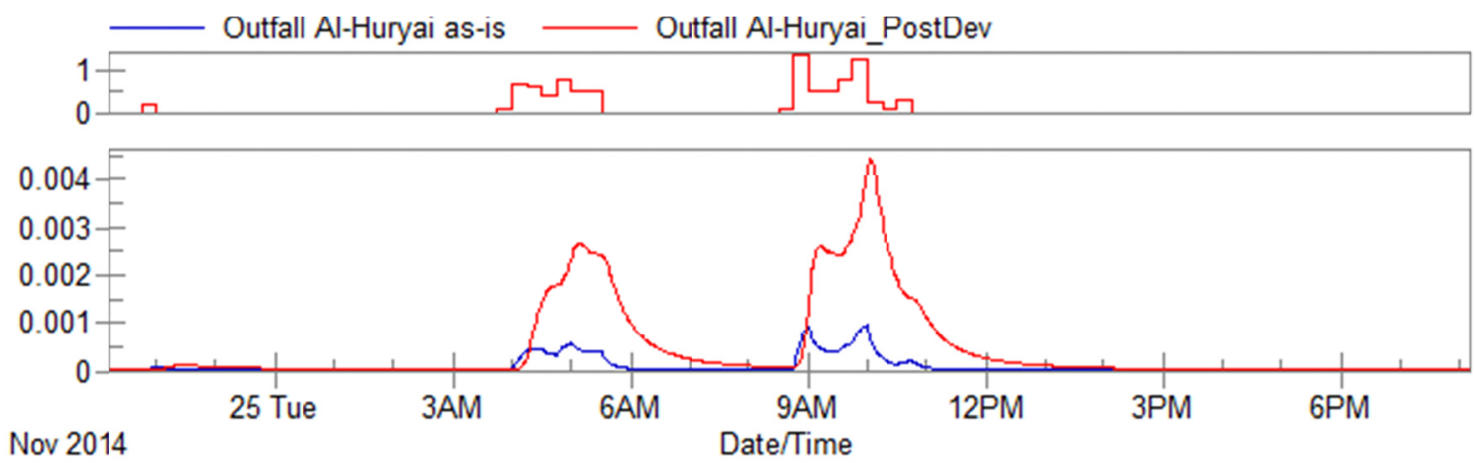

Figure 8. Comparisons simulation between Al-Huryai as-is and Al-Huryai_PosDev at the end of simulation period

The post-development hydrograph in the three figures above show a significant increase in peak discharge and a more rapid decline once the rainfall ceases. The narrow hydrograph (Al-Huryai_PostDev) demonstrates that water from rainfall reaches the outlet quickly and does not infiltrate into the ground. However, the wide hydrograph (Al-Huryai as-is) indicates that a huge amount of rainfall infiltrates into the ground. This phenomenon occurs because the land surface in the pre-development mainly consists of grass that allows water to infiltrate quickly, while the post-development mainly consists of paved areas that do not allow water to infiltrate.

Figure 9 and Table 3 clearly shows that the Al-Huryai-PP scenario was able to reduce the total runoff and peak discharge and thus reduce flooding in the neighborhood. However, it does not meet the pre-development runoff condition. The peak flow rate for Al-Huryai as-is scenario was $0.004 \mathrm{~m}^{3} / \mathrm{s}$, while the peak flow rate for Al-Huryai-PP was $0.009 \mathrm{~m}^{3} / \mathrm{s}$. Therefore it suggested for further work to include other LIDs with the permeable pavements approach such as rain water harvesting to give better results.

The Permeable pavement performance typically varies with rainfall events size. Permeable pavement controls are typically more effective at reducing runoff for smaller events that are more frequent. 


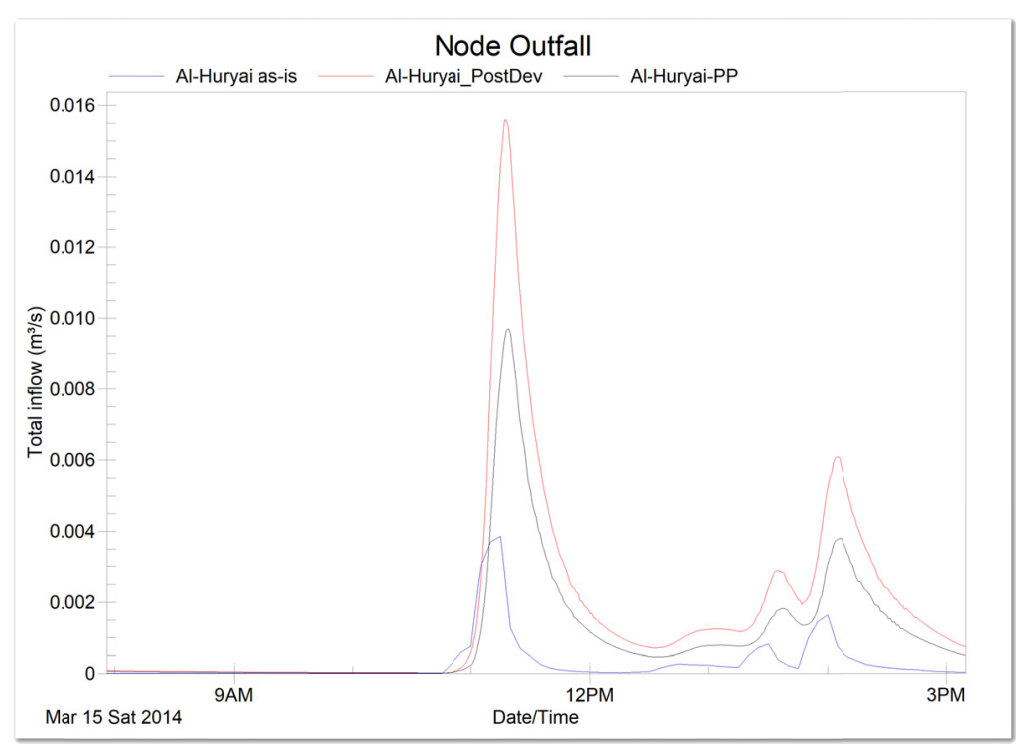

Figure 9. Comparison simulation between the three models

Table 3. Simulation analysis for the three Scenarios

\begin{tabular}{llll}
\hline Simulation period & Al-Huryai as-is & Al-Huryai_PosDev & Al-Huryai-PP \\
\hline From 3-14-2014 to 3-15- 2014 & & & \\
Maximum Total inflow $\left(\mathrm{m}^{3} / \mathrm{s}\right)$ & 0.004 & 0.015 & 0.009 \\
Total inflow $\left(\mathrm{m}^{3}\right)$ & 14.64 & 73.42 & 54.75 \\
\hline
\end{tabular}

\section{Conclusions}

In conclusion, studying permeable pavement as a solution to flooding roads in Baghdad has a significant effect on the environment. The simulation results showed that Al-Huryai-PP scenario was able to reduce the total runoff and peak discharge, thus minimizing flooding. LIDs work best when combined with other techniques such as rainwater harvesting, green roofs, etc. For future studies, including other LIDS with a permeable pavement approach is recommended in order to work toward a cleaner environment.

\section{References}

Abaas, Z. R. (2013). Using green infrastructure in urban sites for sustaining groundwater in Iraq. Journal of Clean Energy Technologies, 1, 169-173.

Abdullah, N. J. (2013). Impervious surface mapping by using satellites imageries for city of Baghdad. Dissertation, Water Resources Engineering Department, Collage of Engineering; Baghdad, Iraq.

Abdulla, S. A. A., Al-Rizzo, H. M., \& Cyrill, M. M. (1988). Particle-size distribution of Iraqi sand and dust storm and their influence on microwave communication systems. IEEE Transactions on Antennas and Propagation, 36(1), 114-126.

Al-Ansari, N., Ali, A. A., \& Knutsson, S. (2014). Present conditions and future challenges of water resources problems in Iraq. Journal of Water Research and Protection, 6, 1066-1098.

Al-Jumaili, M. A. H. (2016). Laboratory evaluation of modified porous asphalt mixtures. Applied Research Journal, 2(3), 104-117.

Chang, N. B. (2018). Global policy analysis of low impact development for storm water management in urban region. Land Use Policy, 70, 368-383.

Crook, J. C. (2009). Climate analysis and long range forecasting of dust storm in Iraq. Thesis; Naval Postgrad School, Monterey: California, US 93943.

Durrans, H. (2003). Stormwater conveyance modeling and design. Haestad Press, Waterbury, CT. Environmental Protection Agency 841-B-09-001: Washington, D.C. 
Eckart, K., McPhee, Z., \& Bolisetti, T. (2017). Performance and implementation of low impact development- a review. Science of the Total Environment, 607-608, 413-432.

El-Mooty, M. A., Kansoh. R., \& Abdulhadi, A. (2016). Challenges of water resources in Iraq. Hydrology of Current Research, 7(4), 1-8.

Gupta, A. (2017). Building a green home using resources and sustainable technology in Jammu region - a case study. Energy Procedia, 115, 50-59.

Haestad Press. (2004). Computer Application in Hydraulic Engineering, Connection Theory to Practice (6th Edition). Haestad Methods, Inc.

James, W. R. C., Rossman, L. E., \& James, W. (2010). User's Guide to SWMM5: Computational Hydraulic International (CHI) (12th edition). USA.

Kfoury, F., Kianmehr, P., \& El-Hassan, H. (2015). Applicability study of permeable pavement in Dubai. WIT Transaction on the built Environment, 168, WIT Press.

Pereze, S., Al-Dabbas, M. A. M., Mohammed, A. A. A., \& Hantosh, T. H. (2017). Study on dust storms climatological trends, transportation paths and source identification. [PowerPoint Slides]. Retrieved from. https://slideplayer.com/slide/10291570/.

Prince George's County. (1999). Low impact development, an integration design approach. Largo, MD: Prince George's County, Maryland. Retrieved from: <http://water.epa.gov/polwaste/green/upload/lidnatl.pdf>.

Shen, M., Chen, J., Zhuan, M., Chen, H., Yu Xu, C., \& Xiong, L. (2018) Estimating Uncertainty and Its Temporal Variation Related to Global Climate Models in Quantifying Climate Change Impact on Hydrology. Journal of Hydrology, 556, 10-24.

Shubbar, R. M., Salman, H. H., and Lee, D. I. (2016). Characteristics of climate variation indices in iraq using a statistical factor analysis. Journal of Climatology, 37, 918-927.

U.S. EPA. (2012). National Pollutant Discharge Eliminating System (NPDES). Stormwater Program. Retrieved from http://cfpub.epa.gov/npdes/home.cfm?program_id $=6$

\section{Copyrights}

Copyright for this article is retained by the author(s), with first publication rights granted to the journal.

This is an open-access article distributed under the terms and conditions of the Creative Commons Attribution license (http://creativecommons.org/licenses/by/4.0/). 